\title{
Nongenetic effects and genetic parameters of the limb measurements in Iranian Turkoman horses
}

\section{Efeitos não genéticos e parâmetros genéticos das medidas dos membros em cavalos turcomanos iranianos}

\author{
Shahabodin GHARAHVEYSI ${ }^{1}$; Hadi GHEZELSOFLOU ${ }^{1}$ \\ ${ }^{1}$ Islamic Azad University, Qaemshahr Branch, Department of Animal Science, Qaemshahr - Iran
}

\begin{abstract}
From the past to now, body conformation is an instrument for the Iranian horse judging. This research aimed to study and estimate the genetic and nongenetic parameters of limb conformation traits in the Iranian Turkoman horses. Therefore, body conformation traits, specifically limb conformation, of 1273 horses were measured. Among the horses studied, 357 stallions and 916 mares were included. For studying the nongenetic (such as sex, province and birth year) and genetic effects (such as additive genetic effect), the LSMEANS procedure and the restricted maximum likelihood method (REML) were used by SAS and MATVEC software, respectively. Birth year had a significant effect on most of the traits, especially scapula length and arm length $(\mathrm{P}<0.05)$. The lowest and the highest heritability was estimated for femur length $(0.11 \pm 0.03)$ and forearm length $(0.40 \pm 0.09)$, respectively. Overall, considering the heritability estimations, the expectation is that limb conformation traits will have a good response to the selection and genetic progress. Farmers can choose the best stallions and mares based on the traits mentioned, so that their foals can have good body conformation.
\end{abstract}

Keywords: Circumference. Conformation. Heritability. Length. Limb.

\section{Resumo}

Do passado para o presente, a conformação corporal é um instrumento para o julgamento de cavalos iranianos. Esta pesquisa teve como objetivo estudar e estimar os parâmetros genéticos e não genéticos das características de conformação dos membros nos equinos turcomanos iranianos. Portanto, as características de conformação do corpo, especificamente a conformação dos membros de 1273 cavalos foram medidas. Entre os cavalos estudados, 357 garanhões e 916 éguas foram incluídos. Para estudar os não genéticos (como sexo, província e ano de nascimento) e efeitos genéticos (como efeito genético aditivo), o procedimento LSMEANS e o método de máxima verossimilhança restrita (REML) foram utilizados pelo software SAS e MATVEC, respectivamente. O ano de nascimento teve um efeito significativo na maioria das características, especialmente comprimento da escápula e comprimento do braço $(\mathrm{P}<0,05)$. A menor e mais alta herdabilidade foi estimada para o comprimento do fêmur $(0,11 \pm 0,03)$ e comprimento do antebraço $(0,40 \pm 0,09)$, respectivamente. No geral, considerando as estimativas de herdabilidade, a expectativa é que as características de conformação do membro tenham uma boa resposta à seleção e progresso genético. Os agricultores podem escolher os melhores garanhões e éguas com base nas características mencionadas, para que seus potros possam ter uma boa conformação corporal.

Palavras-chave: Circunferência. Conformação. Herdabilidade. Comprimento. Membro. 
Correspondence to:

Shahabodin Gharahveysi

Qaemshahr Branch, Islamic Azad University - Tabarsi Road

Qaemshahr- Mazandaran- Iran

Postal code: 4849167119

e-mail: s.gharavysi@gmail.com

Received: $11 / 07 / 2018$

Approved: 26/11/2018

\section{Introduction}

Body conformation is the general shape or outline of an animal. Conformation traits include the body's judging and measurements (BOWLING; RUVINSKY, 2000). Measurement is one of the best and unbiased methods for evaluating body conformation (WELLER et al., 2006). Limb conformation traits have high heritability, and have played an important role in the selection of horses (BOWLING; RUVINSKY, 2000). Long bones are particularly important in a horse, because they form the limbs. They have effects on the height, appearance and quality of gaits. From the anatomical viewpoint, hind limbs and forelimbs are used for starting the stride and supporting the body mass during movement, respectively (KOMOSA et al., 2013). From the past to now, body conformation has been a basic factor in the horse breeding (JÖNSSON, 2013). Horse performance prediction by the body conformation is a long-standing tradition (VAN WEEREN; CREVIER-DENOIX, 2006). Today, according to the traits' correlation, the selection can be done based on conformation traits for improvement of the movement and health traits (KOMOSA; PURZYC, 2009; TAMIOSO et al., 2012).

Genetic and nongenetic factors affect the horse's body conformation. Important nongenetic factors include age, sex, and breeding conditions. These factors should be put in the statistical model for the genetic analysis, then horse selection should be performed (BOWLING; RUVINSKY, 2000). The aforementioned factors interact with genetic factors and affect the horse's conformation and performance (GHARAHVEYSI et al., 2008; YILMAZ et al., 2012). The additive genetic effect is the most important genetic effect, which affects the body conformation and performance traits (MOLINA et al., 1999; GHARAHVEYSI et al., 2008; BOROWSKA et al., 2011).

The Iranian Turkoman horses are among the oldest genetic reserves in Iran and in the world (FOTOVATI, 2000; BAKHTIARI; HESHMAT, 2009). The history of this horse dates over 2500 years. In the past, Turkoman tribes in the northern Iran (provinces of Golestan and Khorasan) bred and kept Iranian Turkoman horses. Akhal-teke, Tchenaran and Yamud (Iomud) are strains of the Iranian Turkoman horse (FOTOVATI, 2000). This breed is assigned to the warm blood group and used for riding, transportation and race (long-distance and short-distance). Researches and information about this horse are limited. The findings of this study will be effective in the scientific identification of the Iranian Turkoman horses. In the scientific identification, the traits are defined and measured. This is based on standardized and defined methods, so that the results of this study can be compared with others.

This research aimed to study and estimate the genetic and nongenetic parameters of limb conformation traits in Iranian Turkoman horses.

\section{Materials and Methods}

\section{Animals Studied}

Limb conformation traits of 1273 Iranian Turkoman horses bred in the Golestan and North Khorasan provinces (northern Iran) were measured. These two provinces are neighbors. Vegetation, climate, and breeding objectives vary in the provinces. The number of racing fields in Golestan is higher than in North Khorasan. This illustrates the interest of the Golestan people in horse breeding. Purchase and sale of horses are carried out between the abovementioned provinces. The horses have a family relationship. In this study, the horses included were 357 males (stallion) and 916 females (mare) whose age ranged from 24 to 300 months and were born from 1989 to 2014 . The strain of the horses used in this study is Akhal-teke. Their traits were measured in 2016 by one person, and each of them was measured once. Pedigree file contained the information of 3824 horses from 11 generations.

\section{Study Characteristics}

In this study, based on the scientific references available, the traits that have the greatest impact on horse's performance were selected (SADEK, 2006; SADEK et al., 2006; GHARAHVEYSI et al., 2008; KOMOSA; PURZYC, 2009; KOMOSA et al., 2013; SOBCSZOK; KOMOSA, 2013). According to the instruction, horses were restrained in a correct position for measuring the limb conformation traits (WELLER et al., 2006; GHARAHVEYSI et al., 2008). Circumference measurements were taken using a tape; and other measurements, using a caliper. The traits measured were as follows (Figure 1): 


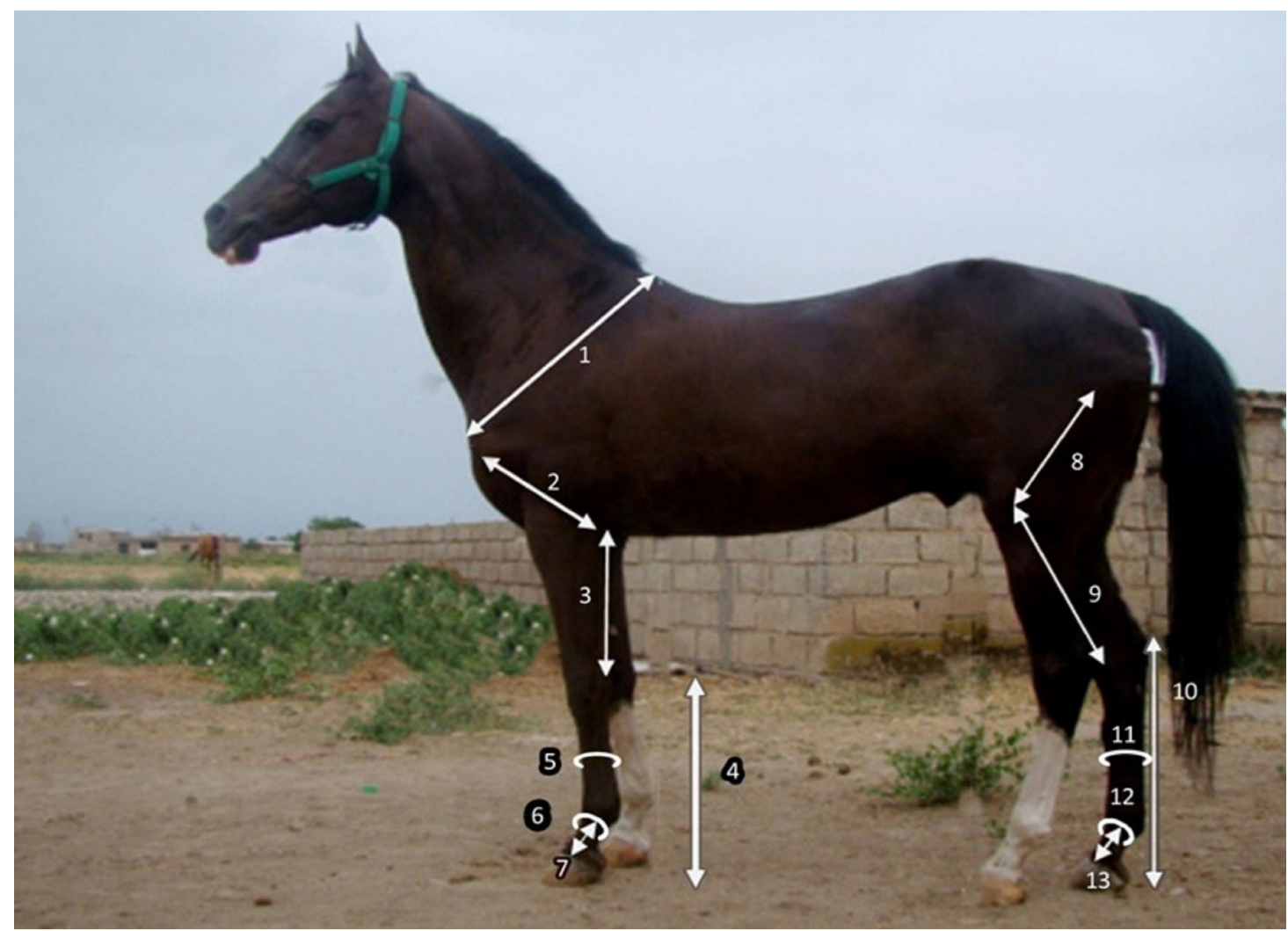

Figure 1 - Left view of the Iranian Turkoman horse for measurements of limb conformation traits

1) Scapula length: distance between the point of withers and the most anterior point of greater tubercle; 2) Arm length: distance between the most anterior point of humerus (greater tubercle) and the olecranon tuber of ulna; 3) Forearm length: distance between the olecranon tuber of ulna and the accessory carpal bone; 4) Hand length: distance between the accessory carpal bone and the ground, vertically; 5) Fore cannon circumference: fore cannon perimeter in the middle section of fore cannon bone; 6) Fore pastern circumference: fore pastern perimeter in the middle section of fore pastern bone; 7) Fore pastern length: distance between the lower joint of fore cannon and the hoof coronary band; 8) Femur length: distance between the greater trochanter of femur and patella; 9) Tibia length: distance between patella and trochlea of talus; 10) Leg length: distance between the calcaneal tuber and the ground, vertically; 11) Hind cannon circumference; 12) Hind pastern circumference; 13) Hind pastern length (Figure 1).

\section{Model and Analysis}

The statistical model was:

$$
\mathrm{y}_{\mathrm{ijk}}=\mu+\mathrm{S}_{\mathrm{i}}+\mathrm{R}_{\mathrm{j}}+\mathrm{B}_{\mathrm{k}}+\mathrm{e}_{\mathrm{ijk}}
$$

In which: $y_{i j k}=$ the value of each observation of each trait; $\mu$ = mean effect; $S_{i}=$ fixed effect of sex $i, i=1$ (male), 2 (female); $R_{i}=$ province-level fixed effect $j, j=1$ (Golestan), 2 (Northern Khorasan); $B_{k}$ : fixed effect of level $k$ of birth year, $\mathrm{k}=1989,1990, \ldots, 2014 ; \mathrm{e}_{\mathrm{ijk}}=$ random residual effect.

To study the nongenetic effects of limb conformation traits and compare means, LSMEANS test was used by SAS software. For predicting the genetic parameters of the traits, restricted maximum likelihood method (REML) and AI-REML algorithm convergence were used. The aforementioned analyses were done using the MATVEC software (WANG et al., 2002). Animal model was used in the matrix format as follows:

$$
y=X b+Z_{a} a+e ; V(y)=A \sigma_{a}^{2}+I \sigma_{e}^{2} ; E(y)=X b
$$

In which: $\mathrm{y}=$ vector of observations for limb conformation traits; $\mathrm{X}=$ corresponding design matrix associating the fixed effect; and $\mathrm{Z}_{\mathrm{a}}=$ corresponding design matrix associating the additive genetic effect; $\mathrm{b}=$ fixed effect vector; $\mathrm{a}=$ vector of additive genetic effect; $\mathrm{e}=$ residual vector; $\mathrm{V}=$ variance; $\mathrm{E}=$ mathematical expectation; $\mathrm{A}=$ additive numerator relationship matrix; $\mathrm{I}=$ identity matrix whose order is equal to the number records; $\sigma^{2}{ }_{a}=$ variance of additive genetic effect; $\sigma^{2}{ }_{\mathrm{e}}=$ residual variance. 


\section{Results}

\section{Nongenetic Factors}

The lowest and the highest number of the horses measured were born in 1989 and 2014, respectively (3175). Descriptive statistics for studying traits are shown in Table 1. The highest and the lowest standard deviation was calculated for the scapula length $(5.45 \mathrm{~cm})$ and hind pastern length $(1.03 \mathrm{~cm})$, respectively. Also, the greatest and the smallest variation coefficient was calculated for the forearm length (5.31\%) and scapula length (10.23\%), respectively.
LSMEANS results showed sex had a significant effect on the scapula length $(P=0.03)$, arm length $(P=0.04)$, fore cannon circumference $(\mathrm{P}=0.04)$, femur length $(\mathrm{P}=0.04)$ and hind cannon circumference $(\mathrm{P}=0.04)$. The male horses are larger than the females (Table 2). The effect of province was significant on the scapula length $(\mathrm{P}=0.04)$ and arm length $(\mathrm{P}=0.04)$. The limb measures of the North Khorasan horses are larger than those of the Golestan horses (Table 2). The effect of birth year was significant on the scapula length $(P=0.03)$, arm length $(P=0.02)$, hand length $(P=0.02)$, fore pastern length $(P=0.01)$, femur length $(P=0.04)$ and hind pastern length $(P=0.01)$.

Table 1 - Descriptive statistics of the limb conformation traits

\begin{tabular}{|c|c|c|c|c|c|}
\hline Traits & Max* & Min* & Mean* & SD* & CV (\%) \\
\hline Scapula Length & 60.13 & 46.24 & 53.29 & 5.45 & 10.23 \\
\hline Arm Length & 39.89 & 26.92 & 33.81 & 2.26 & 6.68 \\
\hline Forearm Length & 45.58 & 33.28 & 39.90 & 2.12 & 5.31 \\
\hline Hand Length & 44.45 & 30.19 & 36.57 & 2.67 & 7.30 \\
\hline Fore Cannon Circumference & 21.98 & 16.79 & 18.80 & 1.20 & 6.38 \\
\hline Fore Pastern Circumference & 21.59 & 16.83 & 18.39 & 1.23 & 6.69 \\
\hline Fore Pastern Length & 14.39 & 10.67 & 12.16 & 1.13 & 9.29 \\
\hline Femur Length & 51.94 & 35.84 & 43.67 & 2.96 & 6.78 \\
\hline Tibia Length & 55.76 & 39.95 & 48.95 & 2.76 & 5.64 \\
\hline Leg Length & 56.79 & 41.23 & 49.43 & 2.84 & 5.75 \\
\hline Hind Cannon Circumference & 22.94 & 18.01 & 20.89 & 1.24 & 5.94 \\
\hline Hind Pastern Circumference & 22.83 & 17.59 & 19.53 & 1.20 & 6.14 \\
\hline Hind Pastern Length & 15.95 & 10.87 & 13.29 & 1.03 & 7.75 \\
\hline
\end{tabular}

${ }^{\star}$ Measure in centimeter; $\mathrm{SD}=$ Standard Deviation; $\mathrm{CV}=$ Coefficient of Variation

Table 2 - Effect of the sex and province on the limb conformation traits

\begin{tabular}{|c|c|c|c|c|}
\hline \multirow{3}{*}{ Traits } & \multicolumn{4}{|c|}{ Factors } \\
\hline & \multicolumn{2}{|c|}{ Sex } & \multicolumn{2}{|c|}{ Province } \\
\hline & Male* & Female* & Golestan* & North Khorasan* \\
\hline Scapula Length & $53.87^{\mathrm{a}} \pm 0.02$ & $48.34^{b} \pm 0.01$ & $49.94^{b} \pm 0.01$ & $54.12^{\mathrm{a}} \pm 0.01$ \\
\hline Arm Length & $35.19^{\mathrm{a}} \pm 0.01$ & $31.09^{b} \pm 0.00$ & $32.00^{\mathrm{b}} \pm 0.00$ & $36.29^{\mathrm{a}} \pm 0.00$ \\
\hline Forearm Length & $39.81^{\mathrm{a}} \pm 0.01$ & $39.01^{\mathrm{a}} \pm 0.00$ & $38.90^{\mathrm{a}} \pm 0.00$ & $39.16^{a} \pm 0.00$ \\
\hline Hand Length & $37.11^{\mathrm{a}} \pm 0.01$ & $36.70^{\mathrm{a}} \pm 0.00$ & $38.10^{\mathrm{a}} \pm 0.00$ & $38.52^{\mathrm{a}} \pm 0.00$ \\
\hline Fore Cannon Circumference & $18.93^{\mathrm{a}} \pm 0.00$ & $17.92^{\mathrm{b}} \pm 0.00$ & $18.65^{\mathrm{a}} \pm 0.00$ & $18.78^{\mathrm{a}} \pm 0.00$ \\
\hline Fore Pastern Circumference & $18.51^{\mathrm{a}} \pm 0.00$ & $18.10^{\mathrm{a}} \pm 0.00$ & $18.34^{\mathrm{a}} \pm 0.00$ & $18.69^{\mathrm{a}} \pm 0.00$ \\
\hline Fore Pastern Length & $12.34^{\mathrm{a}} \pm 0.00$ & $12.12^{\mathrm{a}} \pm 0.00$ & $12.56^{\mathrm{a}} \pm 0.00$ & $12.78^{a} \pm 0.00$ \\
\hline Femur Length & $44.29^{\mathrm{a}} \pm 0.01$ & $40.09^{b} \pm 0.00$ & $42.98^{\mathrm{a}} \pm 0.00$ & $43.56^{\mathrm{a}} \pm 0.00$ \\
\hline Tibia Length & $49.13^{a} \pm 0.01$ & $48.56^{\mathrm{a}} \pm 0.00$ & $48.12^{\mathrm{a}} \pm 0.00$ & $48.45^{\mathrm{a}} \pm 0.00$ \\
\hline Leg Length & $49.98^{a} \pm 0.01$ & $49.00^{a} \pm 0.00$ & $49.12^{\mathrm{a}} \pm 0.00$ & $49.56^{a} \pm 0.00$ \\
\hline Hind Cannon Circumference & $20.91^{\mathrm{a}} \pm 0.00$ & $18.76^{b} \pm 0.00$ & $19.34^{\mathrm{a}} \pm 0.00$ & $20.37^{a} \pm 0.00$ \\
\hline Hind Pastern Circumference & $19.83^{\mathrm{a}} \pm 0.00$ & $19.21^{\mathrm{a}} \pm 0.00$ & $19.50^{\mathrm{a}} \pm 0.00$ & $19.63^{a} \pm 0.00$ \\
\hline Hind Pastern Length & $13.34^{\mathrm{a}} \pm 0.00$ & $13.19^{a} \pm 0.00$ & $13.62^{\mathrm{a}} \pm 0.00$ & $13.81^{\mathrm{a}} \pm 0.00$ \\
\hline
\end{tabular}

* All measures are in centimeters; Means within a row with different superscripts are significantly different $(\mathrm{P}<0.05)$ 


\section{Genetic Factors}

Tables 3 and 4 show the estimation results of variance components and heritability. The lowest and highest heritability was estimated for the femur length $(0.11 \pm 0.03)$ and forearm length $(0.40 \pm 0.09)$, respectively. The additive genetic variance ranged from
0.30 for the hind pastern length to 0.40 for the fore pastern circumference. The residual variance ranged from 0.76 for the hind pastern length to 25.83 for the scapula length. In addition, the phenotypic variance ranged from 1.06 for the hind pastern length to 29.72 for the scapula length.

Table 3 - Variance component and heritability of the fore limb conformation traits

\begin{tabular}{|c|c|c|c|c|c|c|c|}
\hline Factors & $\begin{array}{l}\text { Scapula } \\
\text { Length }\end{array}$ & $\begin{array}{c}\text { Arm } \\
\text { Length }\end{array}$ & $\begin{array}{l}\text { Forearm } \\
\text { Length }\end{array}$ & $\begin{array}{l}\text { Hand } \\
\text { Length }\end{array}$ & $\begin{array}{c}\text { Fore Cannon } \\
\text { Circumf. }\end{array}$ & $\begin{array}{c}\text { Fore Pastern } \\
\text { Circumf. }\end{array}$ & $\begin{array}{c}\text { Fore Pastern } \\
\text { Length }\end{array}$ \\
\hline$\sigma^{2} A$ & 3.89 & 0.73 & 1.79 & 2.01 & 0.34 & 0.40 & 0.36 \\
\hline$\sigma^{2} \mathrm{E}$ & 25.83 & 4.38 & 2.72 & 5.12 & 1.11 & 1.11 & 0.91 \\
\hline$\sigma^{2} P$ & 29.72 & 5.11 & 4.51 & 7.13 & 1.45 & 1.51 & 1.27 \\
\hline$h^{2} \pm S E$ & $0.13 \pm 0.08$ & $0.14 \pm 0.08$ & $0.40 \pm 0.09$ & $0.28 \pm 0.09$ & $0.23 \pm 0.07$ & $0.26 \pm 0.09$ & $0.28 \pm 0.09$ \\
\hline
\end{tabular}

Circumf. = circumference; $\sigma_{\mathrm{A}}^{2}=$ additive genetic variance; $\sigma_{\mathrm{E}}^{2}=$ environmental variance; $\sigma_{\mathrm{P}}^{2}=$ phenotypic variance; $\mathrm{h}^{2}=$ heritability; SE $=$ standard error

Table 4 - Variance component and heritability of the hind limb conformation traits

\begin{tabular}{|c|c|c|c|c|c|c|}
\hline Factors & $\begin{array}{c}\text { Tibia } \\
\text { Length }\end{array}$ & $\begin{array}{l}\text { Femur } \\
\text { Length }\end{array}$ & $\begin{array}{l}\text { Leg } \\
\text { Length }\end{array}$ & $\begin{array}{c}\text { Hind Cannon } \\
\text { Circumf. }\end{array}$ & $\begin{array}{c}\text { Hind Pastern } \\
\text { Circumf. }\end{array}$ & $\begin{array}{l}\text { Hind Pastern } \\
\text { Length }\end{array}$ \\
\hline$\sigma^{2} A$ & 1.90 & 0.94 & 0.95 & 0.40 & 0.37 & 0.30 \\
\hline$\sigma^{2} E$ & 5.73 & 7.82 & 7.09 & 1.14 & 1.07 & 0.76 \\
\hline$\sigma^{2} P$ & 7.63 & 8.76 & 8.04 & 1.54 & 1.44 & 1.06 \\
\hline$h^{2} \pm S E$ & $0.25 \pm 0.07$ & $0.11 \pm 0.03$ & $0.12 \pm 0.05$ & $0.26 \pm 0.09$ & $0.26 \pm 0.07$ & $0.28 \pm 0.08$ \\
\hline
\end{tabular}

Circumf. = circumference; $\sigma_{\mathrm{A}}^{2}=$ additive genetic variance; $\sigma_{\mathrm{E}}^{2}=$ environmental variance; $\sigma_{\mathrm{P}}^{2}=$ phenotypic variance; $\mathrm{h}^{2}=$ heritability; SE = standard error

\section{Discussion}

\section{Nongenetic Factors}

The horse breeding conditions, sex, nutrition, and age are important factors for the body conformation traits (BOWLING; RUVINSKY, 2000; FOTOVATI, 2000; JÖNSSON, 2013). Variation in the mentioned factors leads to difference in the results of studies.

The sex factor in Egyptian Arab horses (SIMČIČ et al., 2012) and year-sex in the Finnhorse trotters (VAN WEEREN; CREVIER-DENOIX, 2006) had a significant effect on most of the body conformation traits. In the mentioned studies, age had a significant effect on the body conformation traits, except for the height at withers. In a study on Posavje horses, age had a significant effect on most of the traits, except for the body length (SIMČIČ et al., 2012). The results of the studies mentioned corroborate the findings of this study.

Variation coefficients of body conformation traits in the Brazilian Pantaneiro horses (MISERANI et al., 2002), Hungarian Thoroughbred broodmares (BENE et al.,
2013) and Pura Raza Española horses (SÁNCHEZ et al., 2013 ) were $2 \%$ to $8 \%, 2.1 \%$ to $6.7 \%$, and $2.3 \%$ to $9.3 \%$, respectively. The results of the aforementioned studies corroborate those of this study.

By comparing the results of this study with the biometric results of studies on German Arabian horses (SIERZCHULSKI et al., 2005), Polish warmblood stallions (BOROWSKA et al., 2011), Purebred Spanish horses (GÓMEZ et al., 2009) and Iranian Arab horses (GHARAHVEYSI et al., 2008), the Iranian Turkoman horses have the best limb conformations. That is, they have thicker and longer bones, and longer legs.

\section{Genetic Factors}

The factors such as sample size, measurement methods, statistical model and estimation methods had effect on the results of genetic estimations. Therefore, for comparing results of studies, the aforementioned factors should be considered.

The heritability estimations of this study corroborate the findings of studies with Arabian horses (0.14 to 0.55) 
(SADEK, 2006), Polish warm blood stallions (0.14 to 0.87) (BOROWSKA et al., 2011), Kladruber horses (0.04 to 0.65) (VAN WEEREN; CREVIER-DENOIX, 2006), Iranian Arab horses (0.050 to 0.614) (GHARAHVEYSI et al., 2008), Iranian Thoroughbred horses (0.22 to 0.49) (BAKHTIARI; HESHMAT, 2009), Andalusian horses (0.35 to 0.95) (MOLINA et al., 1999), Brazilian Pantaneiro horses (0.27 to 0.83) (MISERANI et al., 2002), German Purebred Arab horses (0.05 to 0.160) (SIERZCHULSKI et al., 2005), and Finnhorse trotters (0.53 to 0.78) (SUONTAMA et al., 2009). Heritability estimations for the fore and hind cannon circumference ( 0.27 and 0.32$)$ were higher than for a similar study (0.10 and 0.05) (VAN WEEREN; CREVIER-DENOIX, 2006). The aforementioned estimations corroborate the results for the hind cannon

\section{References}

BAKHTIARI, J.; HESHMAT, G. Estimation of genetic parameters of conformation traits in Iranian Thoroughbred horses. Livestock Science, v. 123, n. 2-3, p. 116-120, 2009. doi: 10.1016/j.livsci.2008.10.014.

BENE, S.; GICZI, A.; NAGY, Z.; BENEDEK, Z.; SZABÓ, F; POLGÁR, P. Live weight and body measurement of Hungarian Thoroughbred broodmares. Journal of Central European Agriculture, v. 14, n. 3, p. 952-962, 2013. doi: 10.5513/JCEA01/14.3.1287.

BOROWSKA, A.; WOLC, A.; SZWACZKOWSKI, T. Genetic variability of traits recorded during 100-day stationary performance test and inbreeding level in Polish warmblood stallions. Archiv fur Tierzucht, v. 54, n. 4, p. 327-337, 2011.

BOWLING, A. T.; RUVINSKY, A. (Ed.). The genetics of the horse. Oxon: Cabi, 2000. 527 p.

FOTOVATI, A. Persian horse breeds from ancient time to present and their rules in development of world horse breeds. Asian-Australasian Journal of Animal Science, v. 13, July 2000. Supplement C, p. 401-410.

GHARAHVEYSI, S.; KASHAN, N. E. J.; GERAMI, A.; TORSHIZI, R. V. Estimation of genetic parameters on conformation traits of the Iranian Arab horses population. circumference (0.33) (SADEK, 2006). The heritability estimation reported for the fore cannon circumference in some studies were 0.30 to 0.55 (MOLINA et al., 1999; SADEK, 2006; GHARAHVEYSI et al., 2008; BAKHTIARI; HESHMAT, 2009; GÓMEZ et al., 2009), which is higher than the estimation for this study.

The estimated heritability for the traits of this study ranges from moderate to high. For this reason, these traits show a response to genetic selection. Farmers can choose the best stallions and mares based on the traits mentioned, so that their foals can have good body conformations.

\section{Acknowledgements}

The authors would like to thank the Islamic Azad University of Qaemshahr for their supports.

Pakistan Journal of Biological Science, v. 11, n. 2, p. 280 284, 2008. doi: 10.3923/pjbs.2008.280.284.

GÓMEZ, M. D.; GOYACHE, F.; MOLINA, A.; VALERA, $M$. Sire $\times$ stud interaction for body measurement traits in Spanish Purebred horses. Journal of Animal Science, v. 87 , n. 8 , p. 2502-2509, 2009. doi: 10.2527/jas.2008-0841.

JÖNSSON, L. Orthopaedic health conformation and longevity in riding horses: a genetic and phenotypic study. 2013. Ph. D. Thesis (Doctorate in Animal Breeding and Genetics) - Faculty of Veterinary Medicine and Animal Science, Sveriges lantbruksuniversitet, Uppsala, 2013.

KOMOSA, M.; FRACKOWIAK, H.; PURZYC, H.; WOJNOWSKA, M.; GRAMACKI, A.; GRAMACKI, J. Differences in exterior conformation between primitive, Half-bred, and Thoroughbred horses: anatomic-breeding approach. Journal of Animal Science, v. 91, n. 4, p. 16601668, 2013. doi: 10.2527/jas.2012-5367.

KOMOSA, M.; PURZYC, H. Konik and Hucul horses: a comparative study of exterior measurements. Journal of Animal Science, v. 87, n. 7, p. 2245-2254, 2009. doi: 10.2527/ jas.2008-1501.

MISERANI, M. G.; MCMANUS, C.; SANTOS, S. A.; SILVA, J. A.; MARIANTE, A. S.; ABREU, U. G. P.; 
MAZZA, M. C.; SERENO, J. R. B. Heritability estimates for biometric measures of the Pantaneiro horse. Archivos de Zootecnia, v. 51, n. 194, p. 107-112, 2002.

MOLINA, A.; VALERA, M.; SANTOS, R; RODERO, A. Genetic parameters of morphofunctional traits in Andalusian horse. Livestock Production Science, v. 60 , n. $2-3$, p. 295-303, 1999. doi: 10.1016/S03016226(99)00101-3.

SADEK, M. H. Estimation of genetic and phenotypic parameters of body measurement and conformation in Arabian horses. Egyptian Journal of Animal Production, v. 43, n. 2, p. 153-162, 2006.

SADEK, M. H.; AL-ABOUND, A. Z.; ASHMAWY, A. A. Factor analysis of body measurements in Arabian horses. Journal of Animal Breeding and Genetics, v. 123, n. 6, p. 369-377, 2006. doi: 10.1111/j.1439-0388.2006.00618.x.

SÁNCHEZ, M. J.; GÓMEZ, M.D.; PEÑA, F.; MONTERDE, J. G.; MORALES, J.; MOLINA, A.; VALERA, M. Relationship between conformation traits and gait characteristics in Pura Raza Español horses. Archiv fur Tierzucht, v. 56, p. 137-148, 2013. doi: 10.7482/0003-943856-013.

SIERZCHULSKI, J.; HELAK, M.; WOLC, A.; SZWACZKOWSKI, T.; SCHLOTE, W. Inbreeding rate and its effect on three body conformation traits in Arab mares. Animal Science Papers and Reports, v. 23, n. 1, p. 51-59, 2005.

SIMČIČ, M.; MESARIČ, M.; POTOČNIK, K. Analysis of conformation traits of the Posavje horse in Slovenia. Slovenian Veterinary Research, v. 49, n. 3, p. 141-148, 2012.
SOBCSZOK, D.; KOMOSA, M. Morphological differentiation of Polish Arabian horses: multivariate analysis. Bulletin of the Veterinary Institute in Pulawy, v. 56, n. 4, p. 623-629, 2013. doi: 10.2478/v10213-012-0110-5.

SUONTAMA, M.; SAASTAMOINEN, M. T.; OJALA, M. Estimates of non-genetic effects and genetic parameters for body measures and subjectively scored traits in Finnhorse trotters. Livestock Science, v. 124, n. 1-3, p. 205-209, 2009. doi: 10.1016/j.livsci.2009.01.017.

TAMIOSO, P. R.; COSMO, T. R.; PIMENTEL, C. M. M.; DIAS, L. T.; TEIXEIRA, R. A. Heritability estimates for body weight and height at withers in Brazilian army horses. Ciência Rural, v. 42, n. 12, p. 2246-2251, 2012. doi: 10.1590/S0103-84782012005000093.

VAN WEEREN, P.; CREVIER-DENOIX, N. Equine conformation: clues to performance and soundness? Equine Veterinary Journal, v. 38, n. 7, p. 591-596, 2006. doi: 10.2746/042516406X159007.

WANG, T.; FERNANDO, R. L.; KACHMAN, S. D. Matvec user's guide. Version 1.03. Lincoln: University of Nebraska, 2002.

WELLER, R.; PFAU, T.; VERHEYEN, K.; MAY, S. A.; WILSON, A. M. Effect of conformation on orthopaedic health and performance in a cohort of national hunt racehorses preliminary results. Equine Veterinary Journal, v. 38, n. 7, p. 622-627, 2006. doi: 10.2746/042516406X159034.

YILMAZ, O.; ERTUGRUL, M.; BOZTEPE, S. Some morphological traits of Arabian horses used for Javelin Swarm (Cirit) game in Erzurum. Journal of Animal Science Advances, v. 2, n. 8, p. 659-663, 2012. 